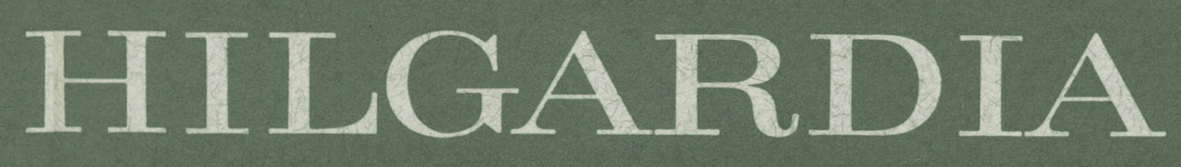

A JOURNAL OF AGRICULTURAL SCIENCE PUBLISHED BY THE CALIFORNIA AGRICULTURAL EXPERIMENT STATION

Volume 34, Number $13 \cdot$ September, 1963

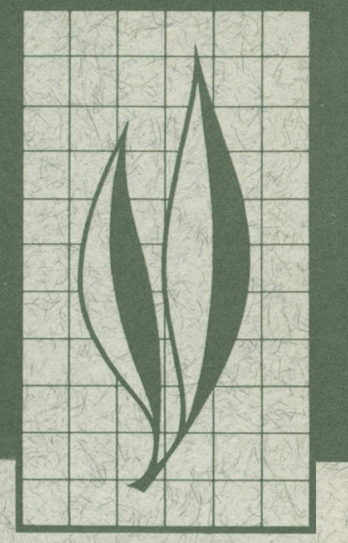

\title{
Relationships Between Plant Growth and Transpiration
}

\author{
Rodney J. Arkley
}




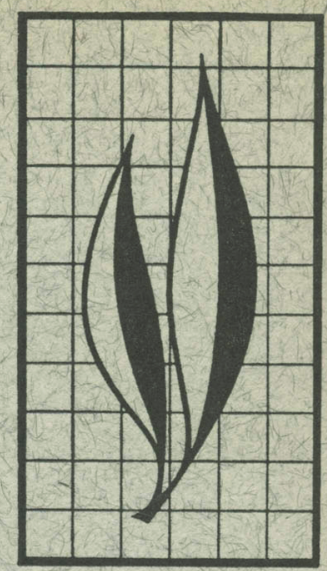

The purpose of this paper is to establish principles for determining the quantitative relationships between climate and plant growth. It is known that the amount of dry matter produced by any plant and the water it transpires are proportional, and that this relation is constant for each plant species or variety under a given set of growing conditions. Using the experimental data of earlier workers, dry-matter production is plotted against water use-separately for each level of soil fertility-and equations are formulated to show the relationships under different conditions. This new analysis of the published data shows that a correction based on atmospheric humidity accounts for about 90 per cent of the variation in the ratio of dry-matter production to transpiration when soil fertility is constant, and that a correction for soil fertility accounts for about 75 per cent of the variation when climate is constant.

These principles are applied to the interpretation of field experiments dealing with water use by plants. They may be useful in determining the most advantageous allocation of limited amounts of irrigation water in different climatic regions, and in many other ways.

\section{THE AUTHOR:}

Rodney J. Arkley is Lecturer in Soils and Plant Nutrition and Specialist in the Experiment Station, Berkeley. 


\section{Relationships Between Plant Growth and Transpiration $^{1}$}

Plant growth is related in a general way to the amount of evapotranspiration that occurs during the growth period (Arkley and Ulrich, 1961, 1962). As the word implies, evapotranspiration is made up of two components: evaporation from the soil and transpiration from the vegetative surface. To study the effects of each component on plant growth, the two must be considered separately.

It is possible to estimate the amount of evapotranspiration during a given period by the "water-balance" approach (Thornthwaite, 1948; Pruitt, 1958), wherein the amount of water available from precipitation, soil moisture, or irrigation is compared with potential evapotranspiration for the period, calculated from climatic data (Penman,
1948; Blaney and Criddle, 1950; Halkias, Veihmeyer, and Hendrickson, 1955; and many others). Evaporation from the soil contributes little to plant growth, except as increased environmental humidity might affect aboveground parts of the plant. Transpiration, on the other hand, is directly involved in the growth of nearly all higher plants.

The purpose of this paper is to show to what extent plant growth and transpiration are related and what factors affect the relationship. Although a great amount of work on this relationship has been published, recent investigators have made little use of the earlier results, apparently because there was no way to compare the results from areas with different climates.

\section{MATERIALS AND METHODS}

The present author has taken data from experiments in the literature, calculated new relationships by means of various equations, plotted regression curves from the resulting ratios, and developed statistical analyses of the situations revealed by the graphs. In every experiment involving transpiration measurements, the plants must be grown in containers and evaporation from the soil must be prevented by an adequate method, such as sealing with wax all openings in the containers. These conlitions were met in every experiment . aited here. For field experiments, the amount of transpiration is estimated from climatic records or from data on the total amount of water available in each experiment, calculated from soilmoisture measurements.

${ }^{1}$ Submitted for publication April 16, 1962. 


\section{GENERAL RELATIONSHIP}

Although most of the water transpired by plants is considered nonessential to the processes of plant growth, transpiration and growth tend to increase together because, obviously, evaporative demands on a plant must be met if the health and vigor of the plant are to be maintained. As Kramer (1959) pointed out, "failure to replace water lost by transpiration results in loss of turgidity, cessation of growth, and eventual death from dehydration."

Graphs were plotted from data of earlier workers: Hellriegel (1883) and Schroeder (1896) for barley, Fortier (1903) for oats, and Wimmer (1908) for carrots. In every case the graphs showed a linear relationship between the amount of dry matter produced $(Y)$ and the amount of water transpired $(T r)$ by a particular species of plant under given conditions of climate and soil fertility:

$$
Y=k T r \quad \text { constant) }
$$

(climate and fertility

The regression coefficient or proportionality constant, $k$, is a parameter that depends on the kind of plant. It is the reciprocal of the transpiration ratio. The slope of the regression line determines its value, which may be expressed as the amount of dry matter produced per unit of water transpired.

Figures 1 and 2, based on data of Briggs and Shantz (1913a) for oats and barley, are typical graphs plotted by the above procedure. In the same way I plotted data of Briggs and Shantz for the weeds Amaranthus retroflexus and $A$. graecizans, and also the data of Kiesselbach (1916) for corn, of Shantz and Piemeisel (1927) for alfalfa, millet, and wheat, of Letey et al (1961) for snapdragons, and-routinely-many other data from the literature. All the graphs showed a linear relationship.

\section{CORRECTION FOR ATMOSPHERIC HUMIDITY}

When a plant has an adequate supply of water and nutrients, its rate of growth increases, within limits, with increasing light and heat. The factors of light and heat usually increase together, at the same time increasing evaporative stress, which the plant meets by increased transpiration-with a simultaneous increase in growth. However, radiation in excess of a plant's needs, or the advective energy of dry air, or both, may cause evaporative stresses that are entirely independent of the stress caused by the growth-promoting light and heat. If the ratios of drymatter production to transpiration are to be compared for different climates, the equation for each experiment must be corrected to reflect advective energy and excess radiation. The following discussion shows that a correction based on relative atmospheric humidity serves this purpose.

Kiesselbach (1916) observed that the slopes of the regression lines for a given crop were different in different years. $\mathrm{He}$ studied the effects of various climatic influences at Lincoln, Nebraska, and concluded that the slope was controlled to a large extent by mean relative atmospheric humidity during July and August, the period of most active growth and transpiration.

Briggs and Shantz (1913a) and, later, Shantz and Piemeisel (1927) showed that there is a relation between $\mathrm{Tr} / \mathrm{Y}-$ the "water requirement" or "transpiration ratio," i.e., the amount of water transpired divided by the yield of dry matter-and $E_{e}$, the amount of evaporation from an evaporation pan. However, they did not investigate the effect 


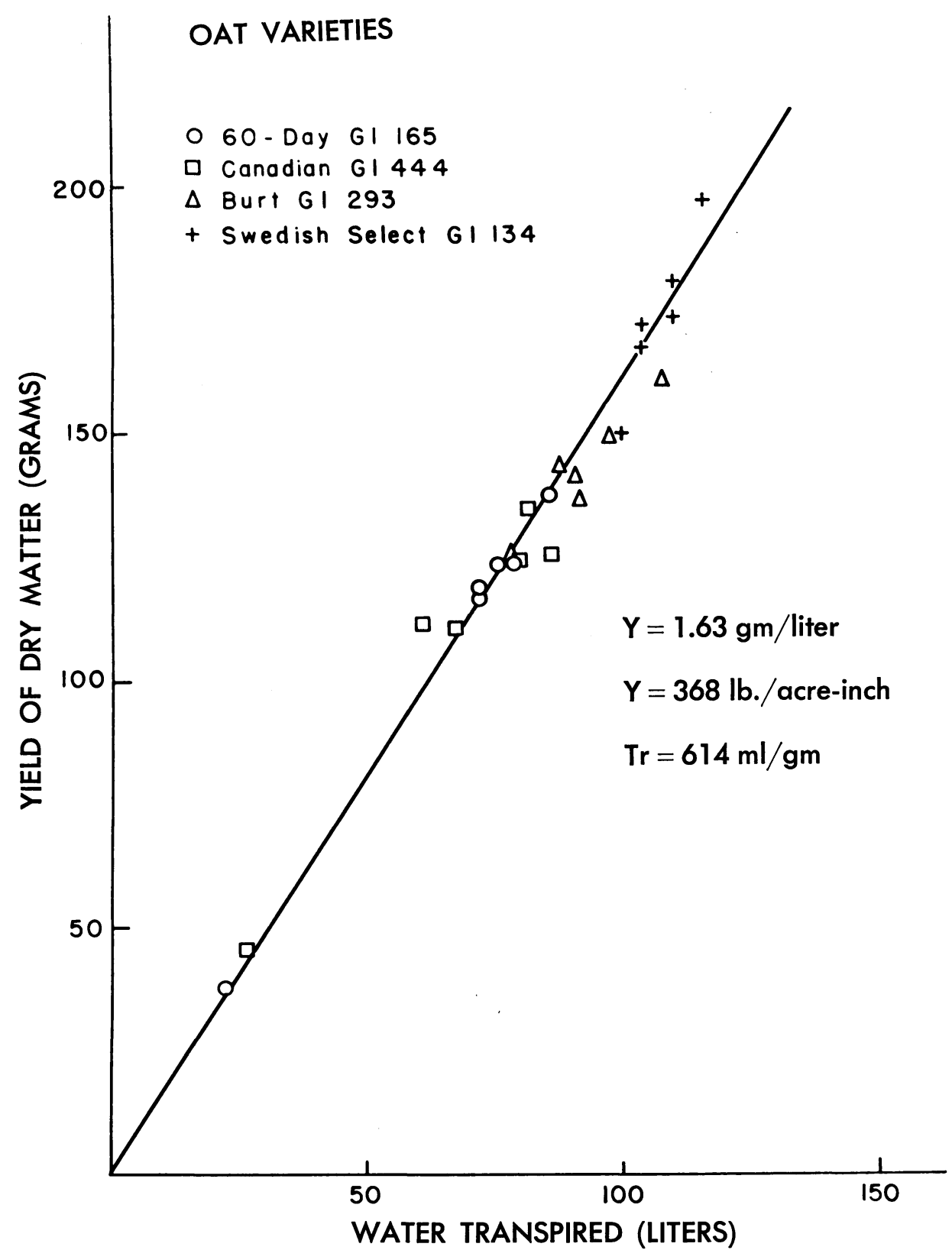

Fig. 1. Relationship between yield of dry matter $(Y)$ and amount of water transpired $(T r)$. Data of Briggs and Shantz (1913a), Colorado.

of relative atmospheric humidity on the transpiration ratio. This effect is tested in figure 3, where data from Shantz and Piemeisel, corrected for mean relative atmospheric humidity ${ }^{2}$, are combined in one graph with the results of Kiesselbach. In this graph, the yield of corn plants in grams of dry matter is plotted

${ }^{2}$ Humidity data were obtained from D. W. Fryrear of the USDA Central Great Plains Experiment Station at Akron, Colorado. 
against $\operatorname{Tr} /(100-H)$, i.e., the amount of transpiration in milliliters of water divided by the relative saturation deficit during the period of most active growth and transpiration. $H$ stands for mean daily relative atmospheric humidity in per cent. Figure 3 indicates that the re- lationship can be expressed in the following form:

$Y=k_{f} \frac{T r}{100-H} \quad$ (fertility constant) (2a)

The parameter $k_{f}$ is a constant for a given kind of plant when the soil is kept

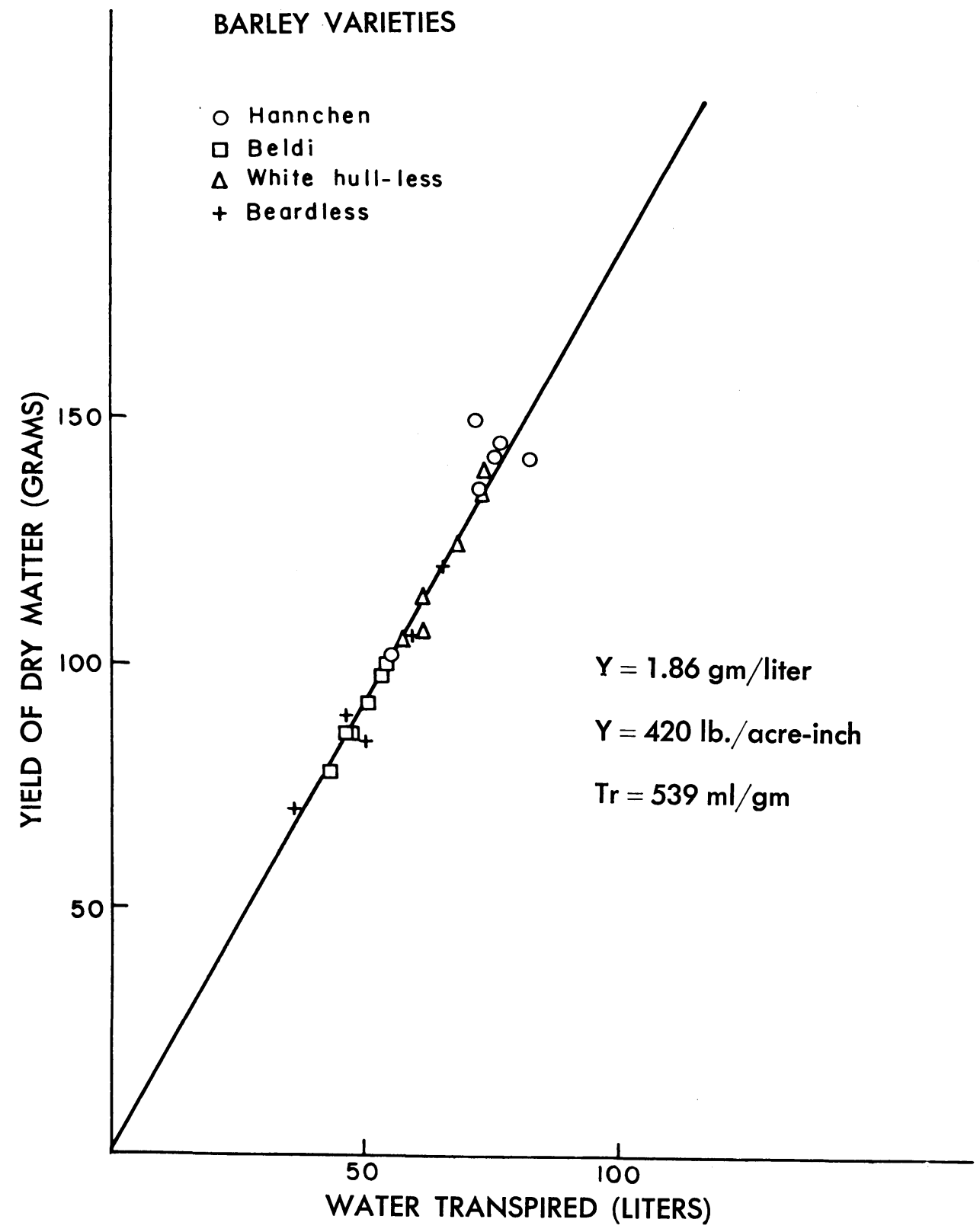

Fig. 2. Relationship between yield of dry matter $(Y)$ and amount of water transpired (Tr). Data of Briggs and Shantz $(1913 a)$, Colorado. 


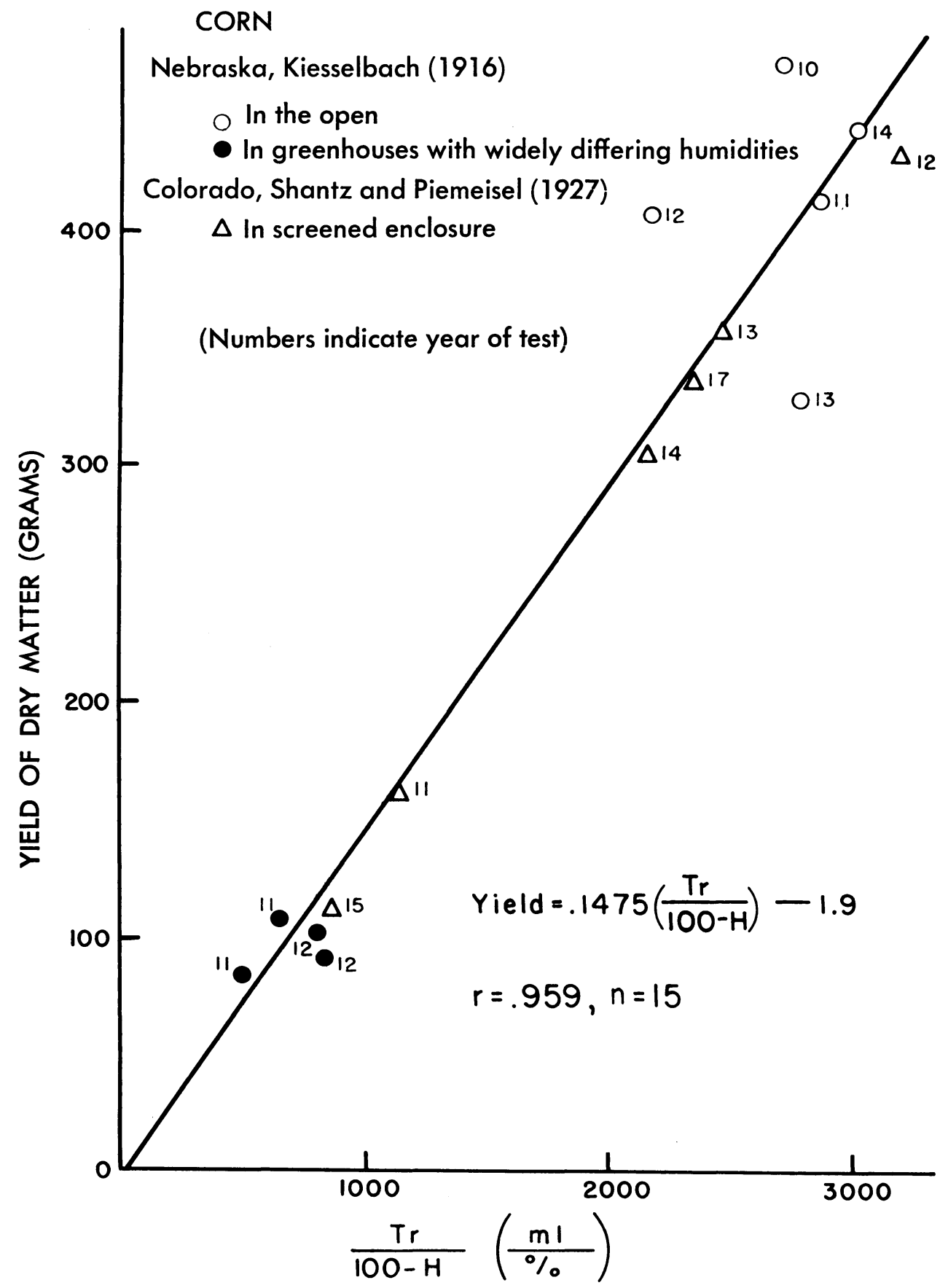

Fig. 3. Effect on the relationship $Y / T r$ of a correction for mean relative atmospheric humidity $(\boldsymbol{H})$ during July and August. 
at a uniform high level of fertility during the entire growth period. Calculated by least squares, the regression equation for figure 3 is $Y=0.1475 \mathrm{Tr} /(100-\mathrm{H})$ $1.9, r=0.959, n=15$. The simpler equation $Y=0.146 \mathrm{Tr} /(100-H)$ serves just as well, because the calculated regression line is not significantly different from one passing through the origin.

De Wit (1958), using data from Briggs and Shantz (1913a, 1914), found that the yield of dry matter at Akron, Colorado, in the semi-arid Great Plains area, was related to the amount of water transpired divided by the amount of water evaporated from an evaporation pan $\left(E_{e}\right)$ :

$$
Y=k^{\prime} \frac{T r}{E_{e}} \quad \text { (fertility constant) }
$$

On the other hand, de Wit found that the function $\operatorname{Tr} / E_{e}$ did not apply in the more humid Netherlands. He considered this a result of the low sunlight intensities in that country and said: "This was to be expected because a great deal of the dry matter is formed during periods in which the sun is obscured by clouds and because at this latitude of 52 degrees the amount of radiation participating in assimilation is much more in June than in September."

The correction based on relative atmospheric humidity-equation (2a)reconciles the conflicting results obtained in the two different climates. In the Great Plains area, the average relative humidity varies considerably from summer to summer (42 per cent at Akron in 1913, 67 per cent in 1915) and contributes greatly to differences in pan evaporation. In the Netherlands, the relative humidity remains at an almost constant high level during the summer and contributes very little to differences in pan evaporation, whereas other factors may affect pan evaporation. At Groningen, the average humidity for June and July is 71.6 per cent, and records from year to year vary from this value only about 4 per cent in either direction. Thus, where humidity remains essentially constant, equation (3) should not give a better correlation than equation (1). In fact, de Wit found that the correlation was diminished by introducing the evaporation factor into the data from the Netherlands.

Both methods-equations (2a) and (3) - applied to the yield and transpiration data for three different crops at Akron, Colorado (Shantz and Piemeisel, 1927), give correlations of about equal accuracy. Figures 4, 5, 6, and 7 show the linear relationships. The regression equations are as shown below:

\section{OATS}

$$
\begin{array}{ll}
Y=0.077 \mathrm{Tr} /(100-H)-1.4 & r=0.974 \\
Y=0.081 \mathrm{Tr} / E_{e}-24.9 & r=0.987
\end{array}
$$

\section{CORN}

$$
\begin{aligned}
Y & =0.140 \mathrm{Tr} /(100-H)+1.0 r=0.996 \\
Y & =0.126 \mathrm{Tr} / E_{e}+2.0 \quad r=0.985
\end{aligned}
$$

\section{SORGHUM}

$$
\begin{array}{ll}
Y=0.178 T r /(100-H)-1.0 & r=0.974 \\
Y=0.151 T r / E_{e}+15.0 & r=0.996
\end{array}
$$

Figure 4 shows also the data of Maschhaupt (1938) and of van der Paauw (1949) for oats in the Netherlands, all corrected for the average relative humidity of Groningen. The regression line for these two sets of data is almost identical with the line for oats in Colorado on the same graph, and the statistical analysis in table 1 shows no significant difference between them. Therefore it appears that, for well-fertilized oats, the relationship expressed in equation (2a) applies equally well in these two very different climates.

Data for peas and for sugar beets were studied in the same way, with similar results. Figure 8 shows Boonstra's (1934) data for peas in the Netherlands, corrected for mean relative atmospheric humidity, together with data for peas in Colorado (Briggs and Shantz, 1913a, 1914). Although the slope of the regres- 


\section{OATS}

\section{Colorado}

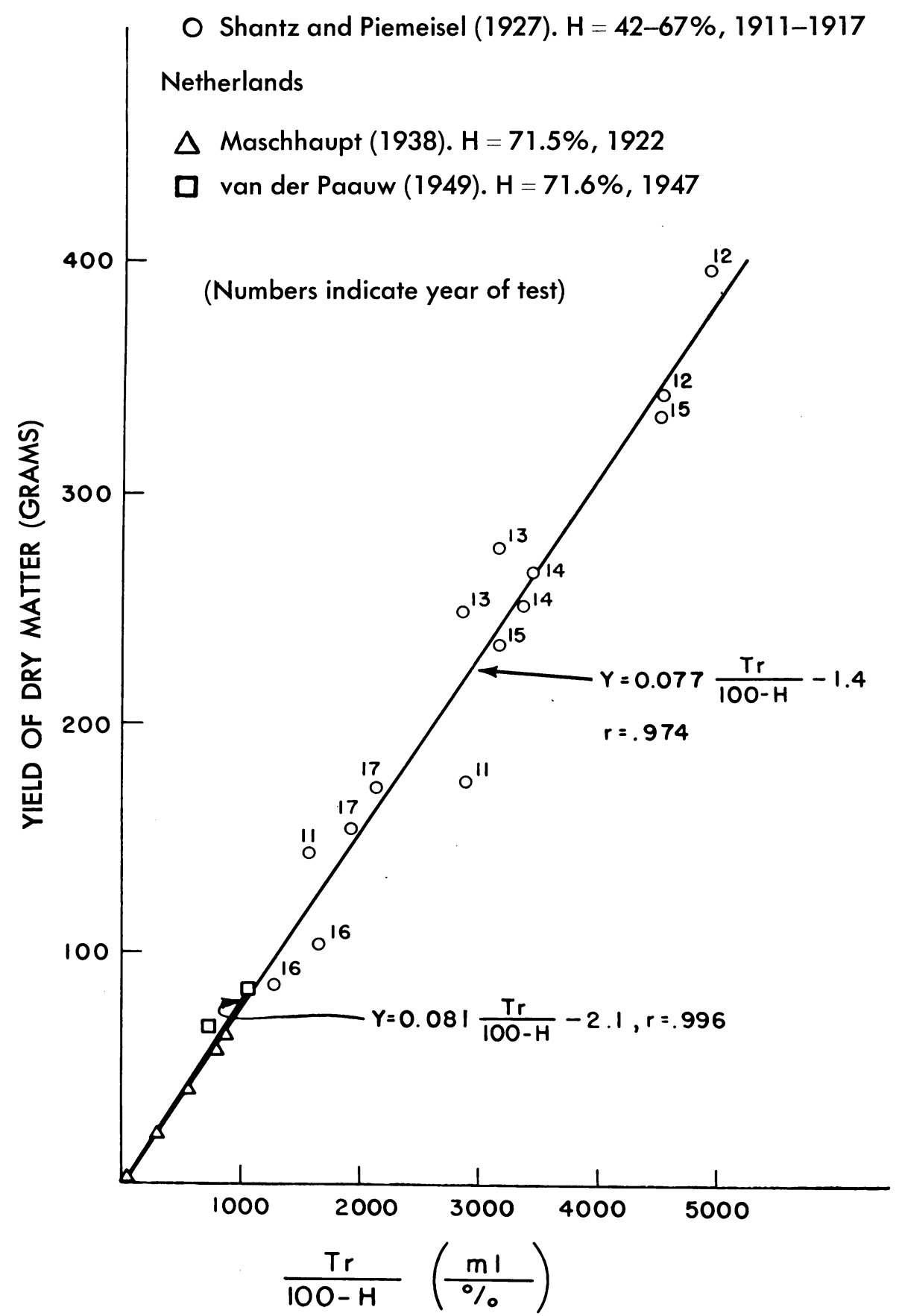

Fig. 4. Effect on the relationship $Y / T r$ of a correction for mean relative atmospheric humidity $(H)$ during June and July, comparing data from Colorado and from the Netherlands. 
sion line for the Netherlands is greater than that for Colorado, only one point from the Netherlands- $Y=30.4, T r /$ $(100-H)=266$ - appears to be significantly divergent from the Colorado regression line.
In another experiment (fig. 9), Boonstra (1934) weighed both tops and roots of pea plants and, of course, obtained a higher average value of $k_{f}$ than for the aboveground yield of pea plants. In spite of large differences in values of

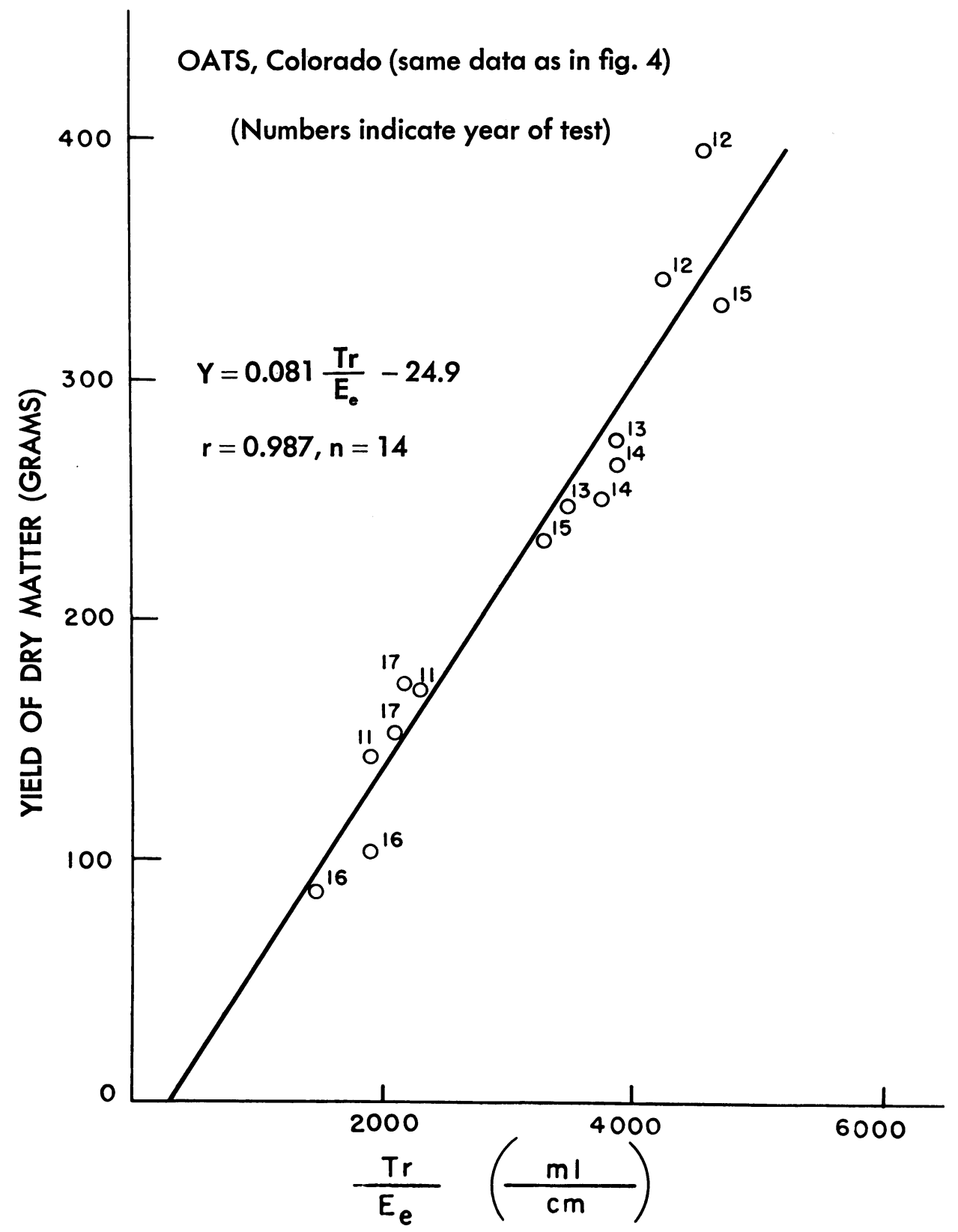

Fig. 5. Effect on the relationship $Y / T r$ of a correction based on pan evaporation $\left(E_{\bullet}\right)$ during June and July. Data of Shantz and Piemeisel (1927). 
free water evaporation (from $1.1 \mathrm{~mm}$ per day in October to 4.6 in June), the scatter of $Y$ plotted against $\mathrm{Tr} /(100-H)$ is only slightly greater than that of $Y$ plotted against $T r$, as in de Wit's figure 28.

For sugar beets, tops plus roots
(Boonstra, 1942), it was not possible to make individual comparisons of points in de Wit's figure 30 with the data of Briggs and Shantz. Table 2 shows data from both regions. Again, the adjustment for mean relative atmospheric humidity seems to bring the results from

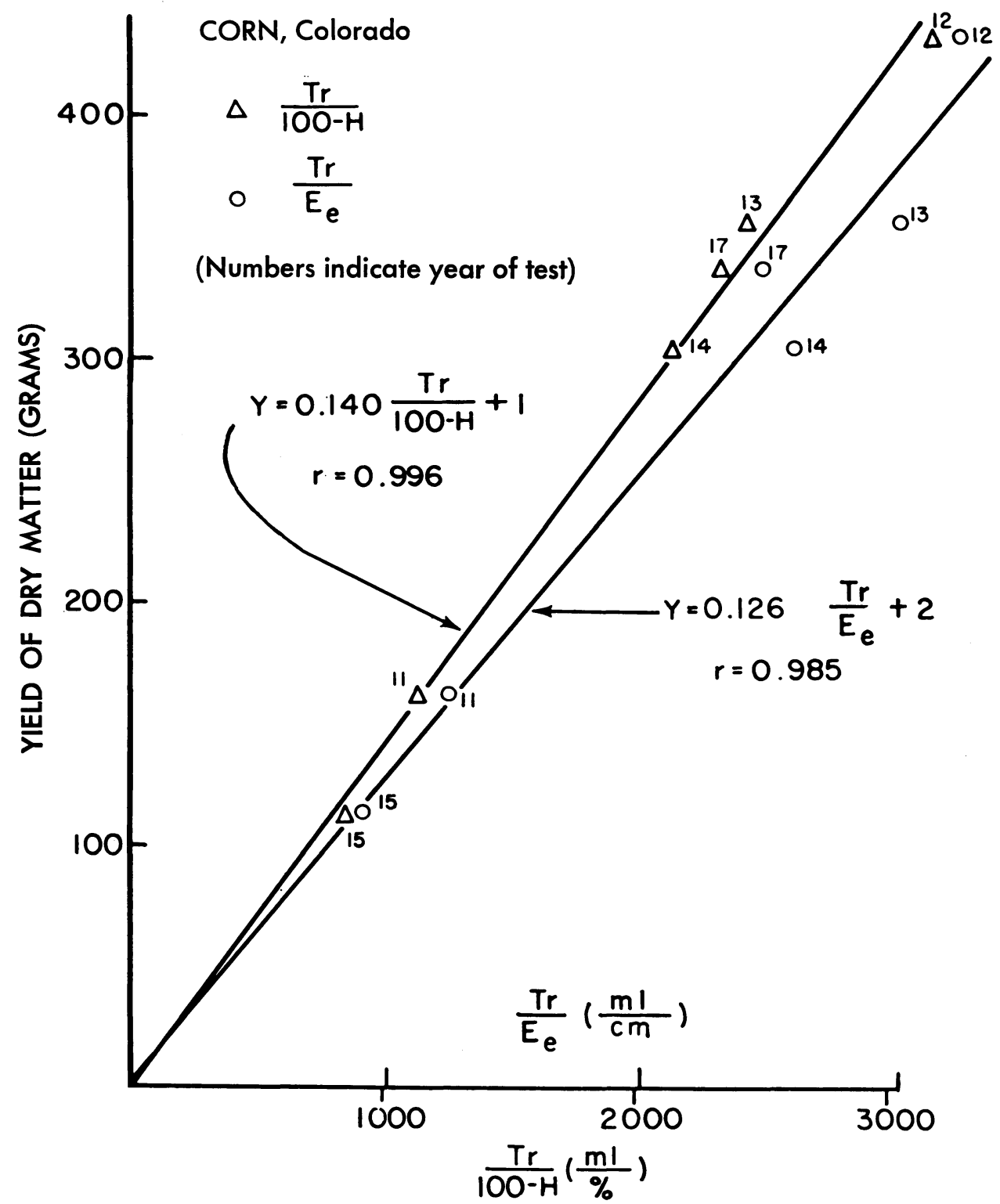

Fig. 6. Comparison of two corrections applied to the same data for yield and transpiration: one correction based on mean relative atmospheric humidity $(H)$ during July and August, the other based on pan evaporation $\left(E_{\bullet}\right)$ during July and August. Data of Shantz and Piemeisel (1927), Colorado. 


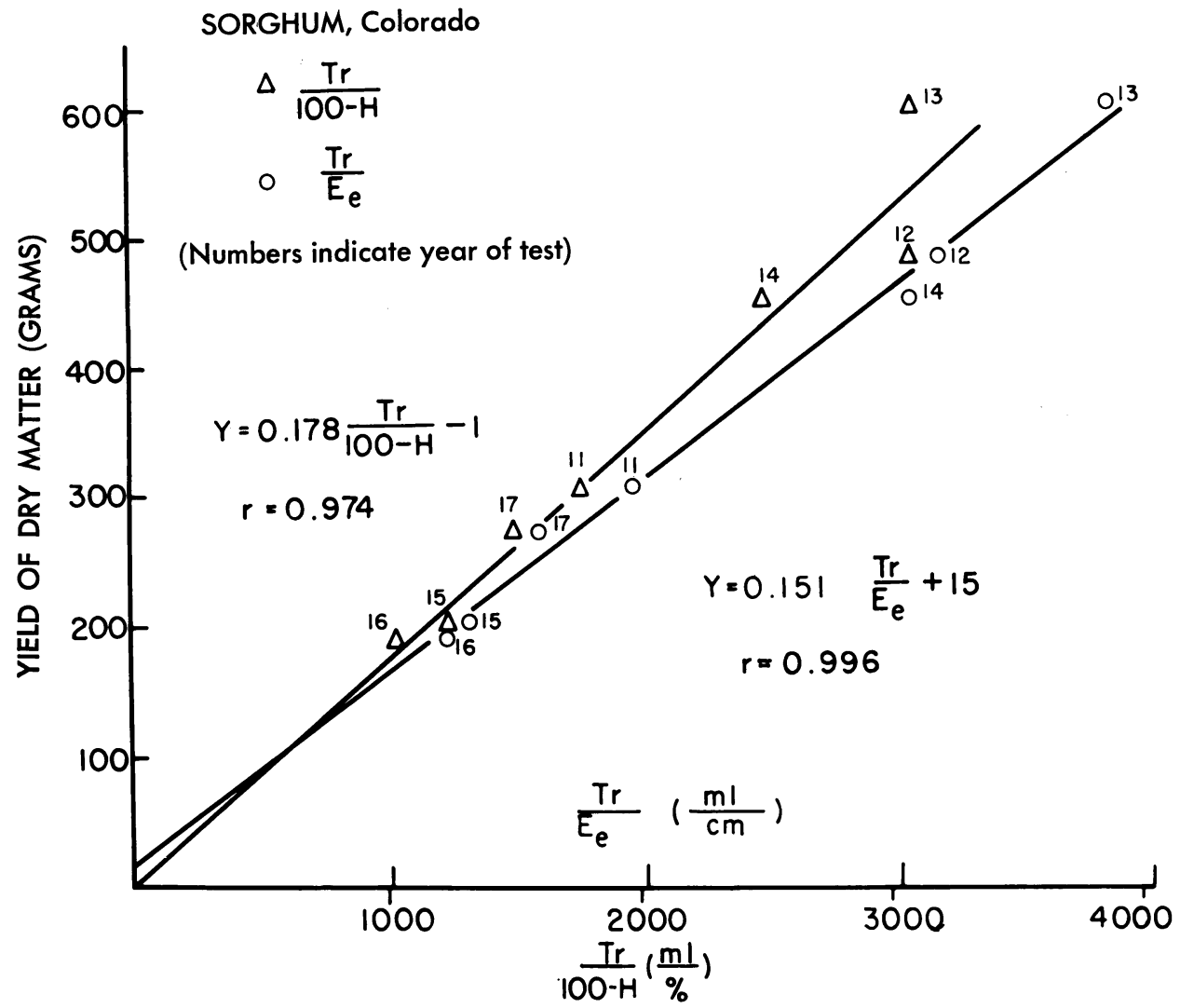

Fig. 7. Comparison of two corrections applied to the same data for yield and transpiration: one correction based on mean relative atmospheric humidity $(\boldsymbol{H})$ during June and July, the other based on pan evaporation $\left(E_{e}\right)$ during June and July. Data of Shantz and Piemeisel (1927).

these two different climates close to a common base. Actually, the average of daily relative humidities (the only available data) for the period of most active growth and transpiration is a rather crude figure. Daytime relative humidities weighted according to the rate of transpiration should give more accurate results. However, the fact that the method used here does reconcile divergent transpiration ratios from very different climates suggests that the relationship in equation (2a) may have general application for crop plants in moderate climates.

The relative vapor pressure deficit $(100-H)$ is used in equation (2a) rather than the absolute vapor pressure deficit

TABLE 1

ANALYSIS OF DATA FOR OATS IN TWO DIFFERENT CLIMATES

\begin{tabular}{|c|c|c|c|c|c|}
\hline Region & $\begin{array}{l}\text { Regression } \\
\text { coefficient }\end{array}$ & $\begin{array}{l}\text { Difference } \\
(D)\end{array}$ & $\begin{array}{c}\text { Standard error } \\
\text { of regression } \\
(E)^{*}\end{array}$ & $\begin{array}{c}\text { Standard error } \\
\text { of difference } \\
\left(E_{D}\right)\end{array}$ & $\begin{array}{l}\text { Ratio } \\
D / E_{D}\end{array}$ \\
\hline $\begin{array}{l}\text { Colorado........... } \\
\text { Netherlands....... }\end{array}$ & $\begin{array}{l}77.24 \\
80.94\end{array}$ & 3.70 & $\begin{array}{l}19.8^{-2} \\
46.6-^{-2}\end{array}$ & 8.15 & $0.454 \dagger$ \\
\hline
\end{tabular}

* Based on the combined value $(Y-\bar{Y})$ and 17 degrees of freedom.

† No significant difference at probability levels from 0.01 to 0.60 . 
$\left(P_{o}-P\right)$, where $P_{o}$ is the saturation vapor pressure and $P$ is the actual vapor pressure of the atmosphere at a given temperature. The yield data for corn in Colorado and Nebraska, plotted in figure 3 against $\operatorname{Tr} /(100-H)$, were replotted in figure 10 against $\operatorname{Tr} /\left(P_{o^{-}} P\right)$. In the second relationship, the data fit a family of straight lines, each theoretically passing through the origin. Their slopes vary with the mean temperature during the period of most active growth and transpiration. As all the points in figure 3 fall along a single line, it appears that the use of $(100-H)$ compensates for a temperature function,

\section{PEAS}

Colorado, Briggs and Shantz (1913a, 1914)

+1911 , June and July

- 1911, September and October

- 1913, June and July

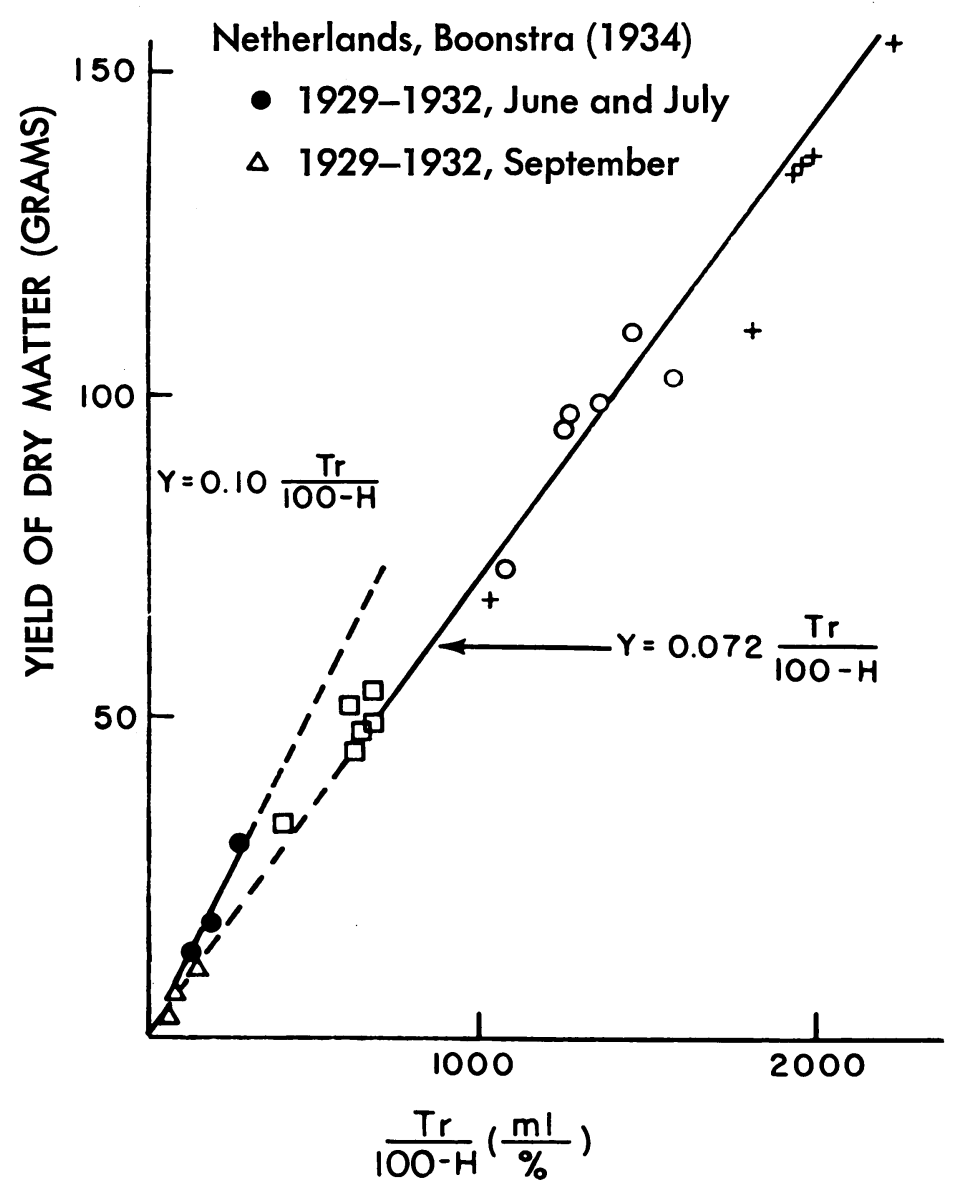

Fig. 8. Comparison of yield and transpiration data from the Netherlands with data from Colorado, all corrected for mean relative atmospheric humidity $(H)$ during the period of most active growth and transpiration. (Compare deWit's fig. 27.) 


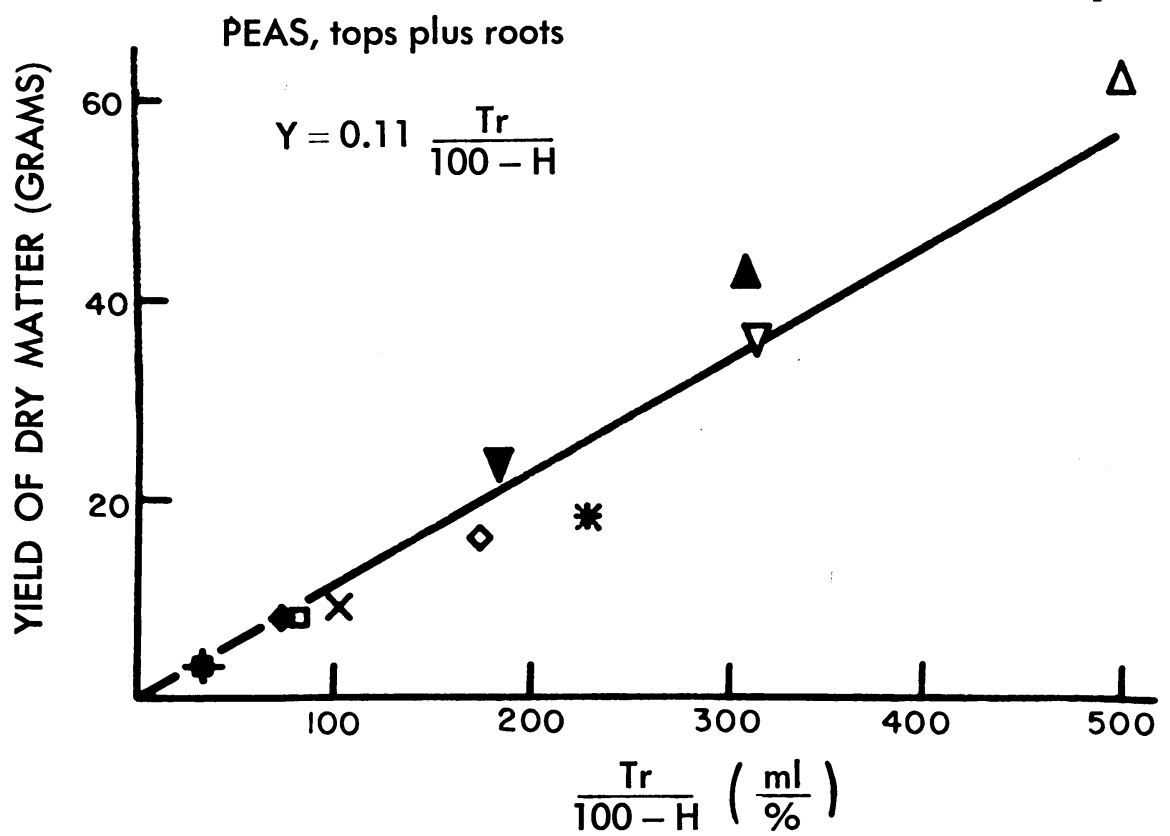

Fig. 9. Effect of correction for mean relative atmospheric humidity $(\boldsymbol{H})$ on the relationship $Y / T r$ where pan evaporation varied widely. Symbols are those of deWit's figure 28, which gives the same data without the correction. Data of Boonstra (1934), Netherlands.

whereas the use of $\left(P_{0}-P\right)$ does not. The data for oats in Colorado and in the Netherlands (fig. 4), recalculated with the correction for absolute vapor pressure deficit, gave results similar to those in figure 10.

The nature of the temperature factor involved is found by comparing the relationship plotted in figure 3 with that in figure 10. By definition, $H=$ $100 \mathrm{P} / \mathrm{P}_{o}$; therefore, equation (2a) may be written also in the form

$$
Y=0.01 k_{f} \operatorname{Tr} \frac{P_{o}}{P_{o}-P}
$$

The main difference between equation (2b) and the relation of yield to $T r$ / $\left(P_{o}-P\right)$, used in figure 10 , is that equation $(2 \mathrm{~b})$ contains an additional temperature-dependent factor, $P_{o}$, in the numerator. The temperature dependence of saturation vapor pressure $\left(P_{o}\right)$ is described by the Clausius-Clapeyron equation, $P_{o}=c e^{R T / L}$, where $T$ is absolute temperature and $c, e, R$, and $L$ are constants.

The use of (100- $H)$ adds the exponential function of temperature and unifies the yield data with relation to transpiration. Plant growth also increases ex-

TABLe 2

COMPARISON OF DATA FOR SUGAR BEETS (TOPS PLUS ROOTS) GROWN IN COLORADO AND IN THE NETHERLANDS

\begin{tabular}{|c|c|c|c|}
\hline & $g m / k g$ & per cent & \\
\hline Colorado, $1912 \ldots \ldots \ldots \ldots \ldots \ldots \ldots \ldots \ldots$ & 3.12 & 61.9 & 0.120 \\
\hline 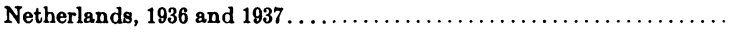 & 6.1 & 76.0 & 0.146 \\
\hline
\end{tabular}

* Data of Briggs and Shantz (1913a, 1914) and of Boonstra (1942).

$\dagger$ Average value.

¥ Average relative atmospheric humidity, July-September.

$\$$ See equation $(2 \mathrm{a})$. 
ponentially with temperature, with $\mathbf{Q}_{10}$ approximately 2 (i.e., an increase of 10 degrees absolute results in approximately twice the growth). In like manner, vapor pressure increases with temperature. Therefore, it may be concluded that the use of relative vapor pressure deficit in equation ( $2 a$ ) is fundamentally sound; also, it is more useful than the absolute vapor pressure deficit for studying the relationship between plant growth and transpiration, because a proper temperature variable is inherent in the relative humidity values.

\section{DIFFERENCES IN PLANT SPECIES}

Shantz and Piemeisel (1927) reported large differences in water requirement $(\mathrm{Tr} / Y)$ between plants of different species but only small differences among varieties of the same species. They determined the water requirement for a number of plants grown at Akron, Colorado, in highly fertile soils. For several years, during which the relative humidity in June, July, and August-the period of maximum growth-averaged about 53.5 per cent, the average water requirement varied from $260 \mathrm{ml} / \mathrm{gm}$ for tumbleweed to $844 \mathrm{ml} / \mathrm{gm}$ for alfalfa. The value of $k_{f}$ in equation (2a) is apparently a constant for a given plant species in soils of high fertility. To estimate the value of $k_{f}$ from the water-requirement data of Shantz and Piemeisel, it is necessary only to multiply the reciprocal of the water-requirement value during the period of maximum growth by $(100-H)-$ in this particular case, multiply by (100-53.5).

\section{AVAILABILITY OF WATER TO PLANTS}

De Wit (1958) examined the data for 18 experiments in which soil moisture was varied in several different ways. The data on yield in relation to transpiration were "arranged around a straight line through the origin"; the only important deviation from the straight line was the decline in yield per unit of water transpired at very high soil moistures. De Wit considered that "it is justified to associate the adverse effect of high saturation percentages with bad aeration of the root system." In sum- mary, he stated that the transpiration ratio was "at first approximation independent of ... availability of water, provided...the availability of water [is] not 'too high'." Apparently this is true in spite of the fact that the growth rate declines as soil moisture is depleted, as has been shown in many cases (Hagan, Vaadia, and Russell, 1959). Evidently this occurs because transpiration and growth decline simultaneously, so that an essentially constant transpiration ratio is maintained.

\section{EFFECT OF SOIL FERTILITY}

All the experiments discussed so far were carried out on highly fertile or heavily fertilized soils. Kiesselbach's (1916) data, corrected for the effect of relative humidity, illustrate the decrease in transpiration ratio $(T r / Y)$ with increasing soil fertility (fig. 11). The transpiration ratio fell rapidly when manure was added to the least fertile soil. In the more fertile soils, where the addition of manure gave increments of acid-soluble phosphate higher than 0.1 per cent of the soil weight, the transpiration ratio fell slowly. The shape of the curve suggests that the transpiration ratio approaches a minimum as the fertility level of a soil increases. In this experiment, the data indicate that phosphate was the more limiting element in fertility, although 
nitrogen and phosphate applications varied concurrently because manure was the source of both.

Of 26 experiments that Briggs and Shantz (1913b) summarized from the literature on the effect of fertilizers and nutrient cultures on the transpiration ratio, the majority showed the same relationship as that in figure 11. Using some of these data and also data of Kiesselbach (1916), the curve in figure 12 evaluates the effect of soil fertility on the transpiration ratio or, more precisely, on its reciprocal, the value $k$ in equation (1). For each level of fertility, the growth-response factor $\left(Y^{\prime}{ }_{f} / Y^{\prime}\right)-$ the relative fertility of the soil or plantgrowth medium-was calculated by dividing the maximum yield $\left(Y_{f}^{\prime}\right)$ obtained in the series of experiments by the yield $\left(Y^{\prime}\right)$ in a given test. This fac- tor was plotted against $k_{f} / k$, the value of $k$ for the most fertile soil $\left(k_{f}\right)$ divided by the value of $k$ for the given fertility level. The regression equation calculated from 52 measurements is

$$
\frac{k_{f}}{k}=0.38 \frac{Y_{f}^{\prime}}{Y^{\prime}}+0.69
$$

(climate

and the correlation coefficient $(r)$ is 0.87 . In other words, plants grown in a soil of 50 per cent relative fertility, as determined in greenhouse tests, produce only about 70 per cent as much dry matter per unit of water transpired as do plants in a soil of 100 per cent fertility. Equation (4) can be considered only approximate, because the points in figure 12 scatter considerably about the line. The scatter is not surprising, in view of the fact that the points repre-

CORN (same data as in fig. 3)

Nebraska, Kiesselbach (1916)

o In the open

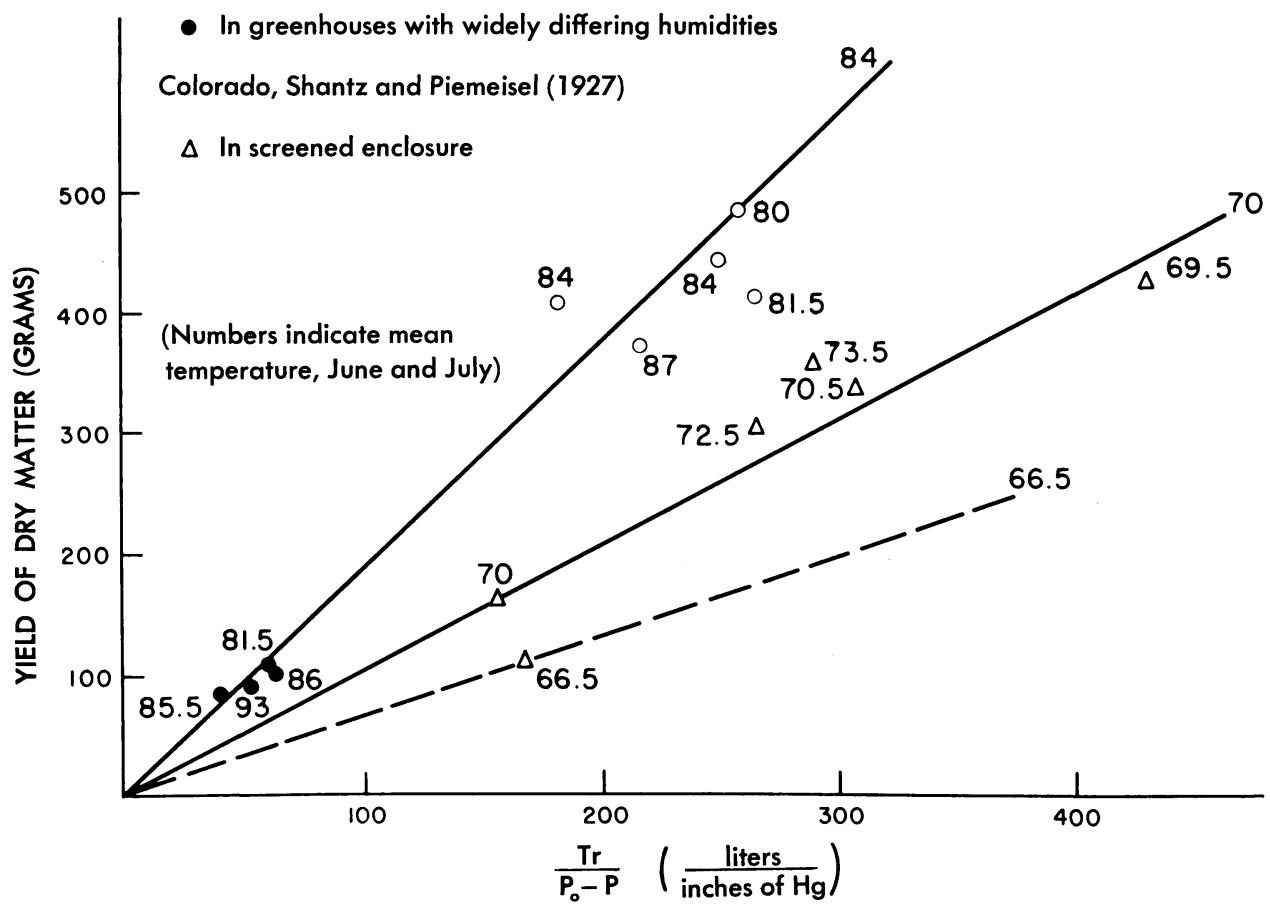

Fig. 10. Effect of temperature on the relationship $Y / T r$ as corrected for absolute vapor pressure deficit of the atmosphere $\left(P_{0}-P\right)$. 
sent the individual data of many workers, who used different plants as well as methods that varied considerably. In spite of this, the correlation is remarkable. For a deficiency of either nitrogen or potassium, calculated separately, regression coefficients are not significantly different from the regression coefficient of the line in figure 12 .

In the relationship between transpiration and plant growth, the available data do not permit determining a possible interaction between the effects of relative humidity and those of soil fertility. Regression coefficients based on the data for figure 11 are not signifi- cantly different for the years 1911 and 1914. This might suggest that such interaction is not important, except that the difference in relative humidity between the two years was only 8.4 per cent $(59.0-50.6)$. More research is needed, to cover a wider range of relative humidities.

However, if we assume that there is no important interaction between the effects of relative humidity and those of soil fertility, we can combine equations (2a) and (4) and obtain

$$
Y=\frac{k_{f} T r}{(100-H)\left(0.38 Y_{f}^{\prime} / Y^{\prime}+0.69\right)}
$$

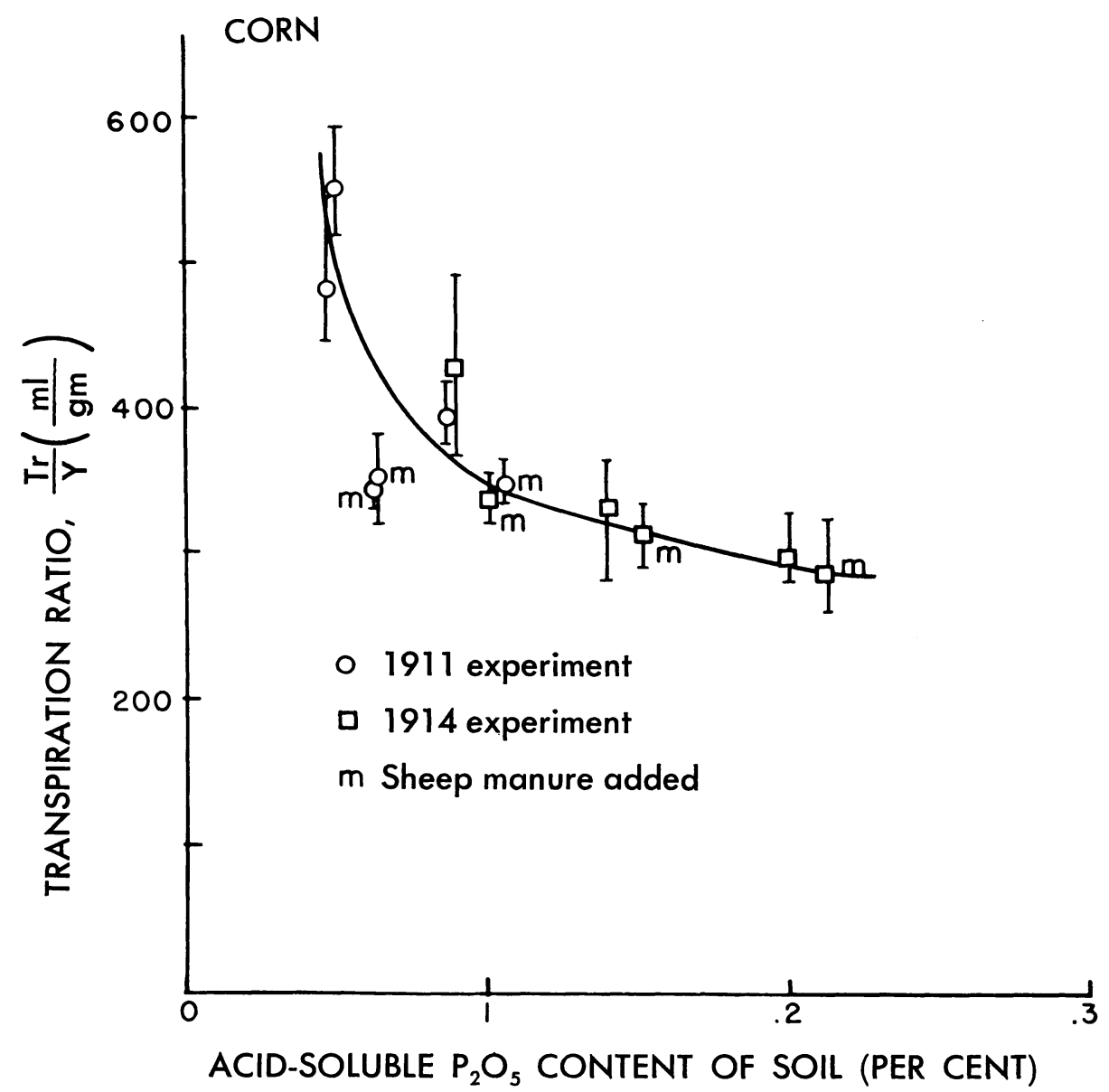

Fig. 11. Effect of soil fertility on the transpiration ratio: Different amounts of phosphate in soil measured by acid extraction, using three different soils, with and without manure; water supply constant. Each point is the mean of three or four pots; vertical bars indicate range of values about the mean. Data of Kiesselbach (1916), Nebraska. 


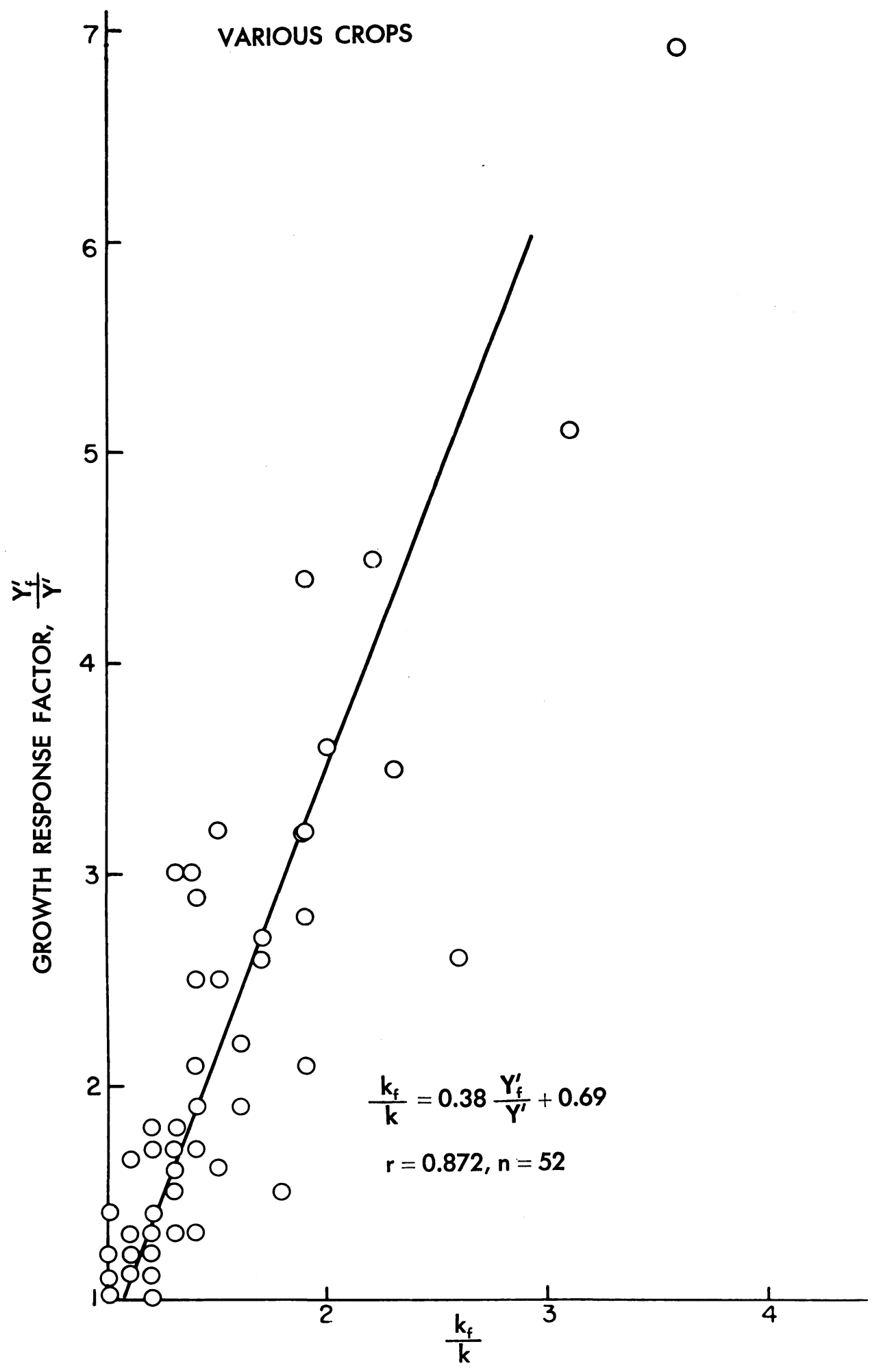


In view of the scatter in figure 12 , equation (5) cannot be expected to predict yields more accurately than \pm 26 per cent. However, the relationships shown here between plant growth, climate, and soil fertility are certainly real and, with further refinement of the parameters, a knowledge of the principles involved should be useful in the study of plantclimate and plant-soil relationships.

\section{TRANSPIRATION AND PLANT GROWTH IN THE FIELD}

To test the application to field conditions of the relationships developed above, I analyzed the duty-of-water experiments with alfalfa at Davis, 1910 1915, reported by Beckett and Robertson (1917). Figure 13 shows the results. At first glance there seems to be little consistency in the data, except that yields increased with increasing amounts of irrigation water up to about 36 inches but leveled off or decreased with additional irrigation. Because the potential evapotranspiration during a season is limited, the plants apparently could use no more than 36 inches of water, and the surplus was wasted by percolating below the reach of the roots.

For 1910, 1911, and 1912, projection of the regression lines to zero precipitation suggests that from 2.9 to 4.7 tons of alfalfa were produced as a result of moisture which is unaccounted for by either rainfall or irrigation. Presumably additional water was obtained by the plants from a water table or from lateral movement in aquifers, which are common in the Yolo soils at Davis. De Wit (1958) drew the same conclusion. For 1913,1914 , and 1915 , when the situation was quite different, figure 14 shows the results separately-omitting data for irrigation quantities above $24-36$ inches, where there were no further important increases. In these years, yield was re- lated by straight lines to the amount of water used by the plants, except for point $A$ in 1913, in a plot which received no irrigation: Evidently the plants obtained a little water from some source in addition to the rainfall of 8.7 inches. Omitting point $A$, each of the regression lines in figure 14 has a correlation coefficient greater than 0.99 .

The values of $k_{f}$ in equation (2a), calculated for field-grown alfalfa at Davis from data on relative humidity at Sacramento, 13 miles east of Davis, were 0.071 for $1913,0.079$ for 1914 , and 0.074 for 1915 . They appear to be higher than the values of $k_{f}$ for alfalfa grown in containers at Akron, Colorado, from 1911 to 1917 , which ranged from 0.070 to 0.046 (data of Shantz and Piemeisel). There are several possible explanations: The Yolo soil at Davis is highly fertile and may have been even more fertile than the fertilized soil used at Akron. Different varieties of alfalfa were used in the two sets of experiments. Also, plants grown in containers, as at Akron, tend to receive more advective energy from wind than do plants growing in larger field plots, as at Davis, because of a more pronounced "border effect."

A projection of the 1914 line intercepts the axis $(Y=0)$ at 18.1, and a projection of the 1915 line intercepts it at 10.3, indicating the amounts of

Fig. 12. Effect of soil fertility on the transpiration ratio. Data as follows: Amount of $\mathrm{K}$ varied: Data of Hellriegel (1883) for barley; data of Wilfarth and Wimmer (1902) for buckwheat, chicory, mustard, tobacco. Amount of $\mathrm{NO}_{3}$ varied: Data of Hellriegel (1883) for barley; data of Wilfarth and Wimmer (1902) for buckwheat, chicory, oats. Amount of NPK varied: Data of Liebscher (1895) for oats. Amounts of NPK and manure varied, separately and in combination: Data of Dehérain (1892) for raygrass (ryegrass) and clover. Amount of manure varied: Data of von Seelhorst (1899) for oats. All of these tests-in France and Germanywere summarized by Briggs and Shantz (1913b). Data of Kiesselbach (1916) for corn in $\mathrm{Ne}$ braska, in three soils, with and without manure (same data as in fig. 11). 
water lost to the plants by evaporation or by percolation beyond root depth. Subtracting the unused amounts of water from the amount of seasonal rainfall leaves 10.6 inches of precipitation available to the plants in 1914 and 10.2 inches in 1915. In 1913 there were only 8.7 inches of rainfall, so no percolation loss would be expected; the fact that the projection of the straight portion of the 1913 line passes through the origin suggests that any rainwater lost by evaporation was probably compensated for by water from some other source, as in 1910, 1911, and 1912. The linearity of the curves suggests that

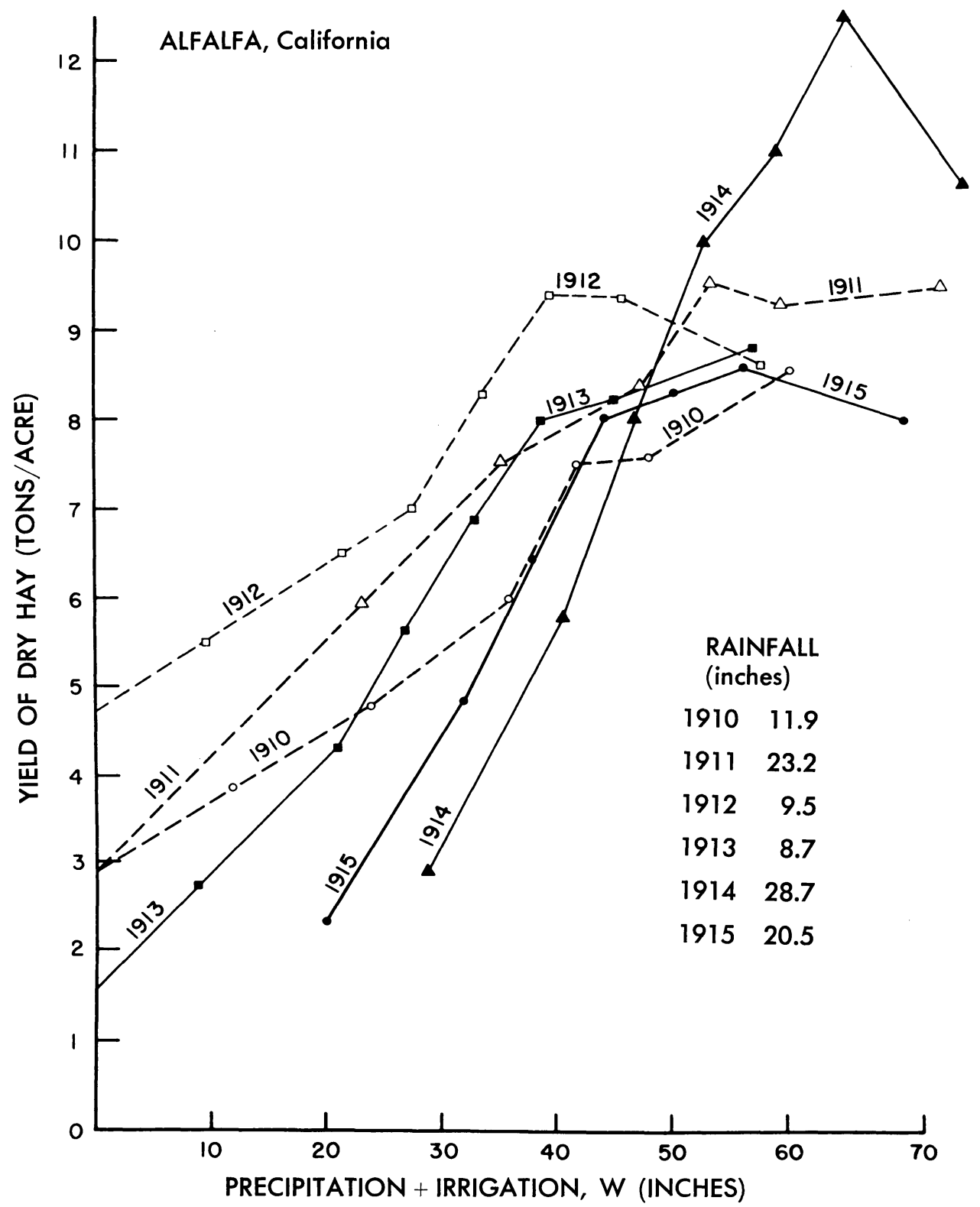

Fig. 13. Relationship between yield of dry hay and total amount of water $(W)$ supplied by precipitation and irrigation. Field data of Beckett and Robertson (1917). 
very little of the irrigation water added, up to 24 to 36 inches, was lost either by evaporation or by deep percolation.

Similar interpretations of the rela- tionship between yield and water use can be made for wheat and barley grown at Davis in 1913, reported by Beckett and Huberty (1928). Both regression

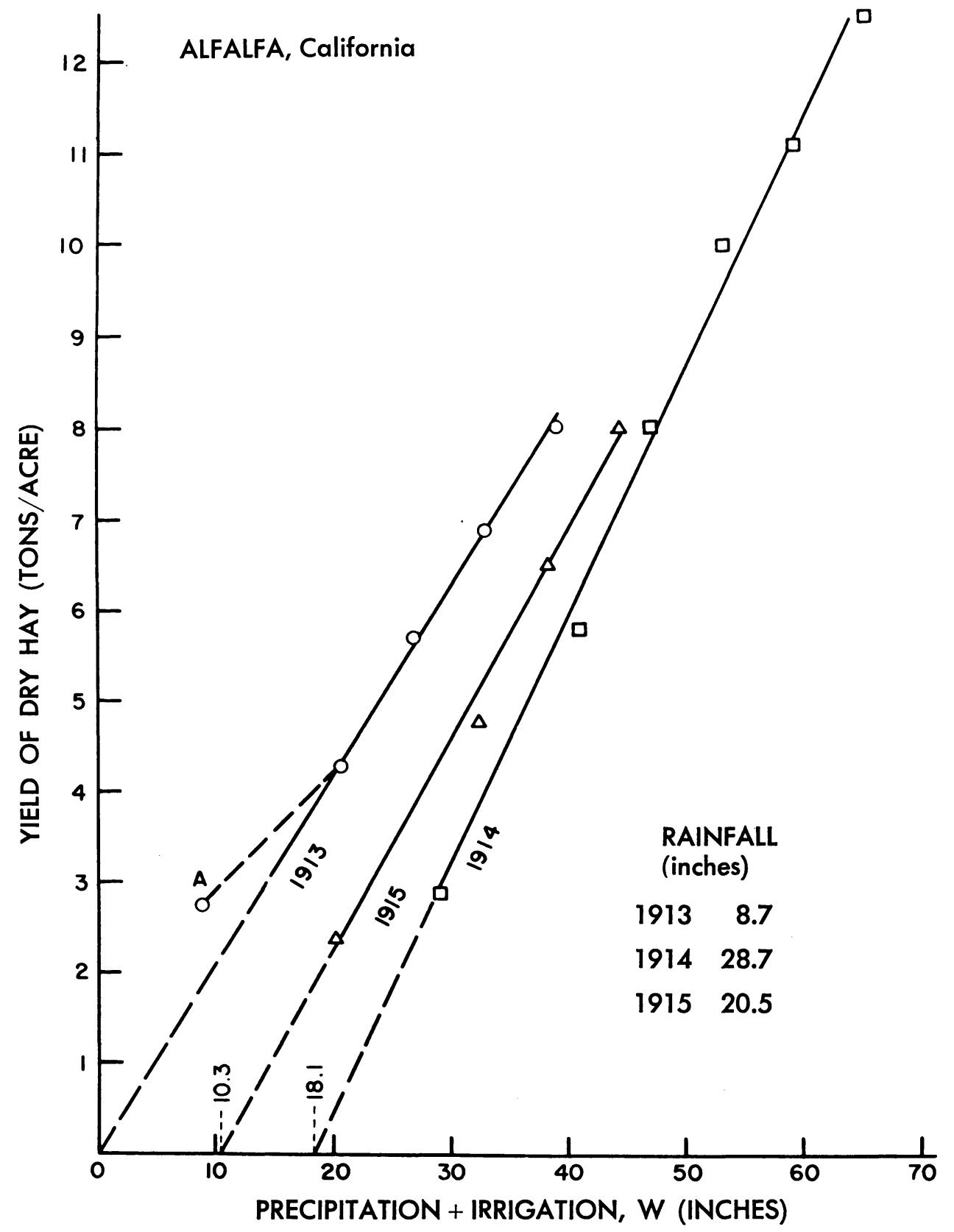

Fig. 14. Relationship between yield of dry hay and total amount of water ( $W$ ) supplied by precipitation and irrigation. Same data as in fig. 13, using the curves for only three of the six years and omitting data for irrigations that did not increase yields. Field data of Beckett and Robertson (1917). 
lines (fig. 15) intercept the axis $(Y=0)$ between 7 and 8 inches of added water, indicating the amount of water lost to the plants. As the rainfall at Davis in 1913 was only 8.7 inches, it appears that less than 2 inches of the precipitation was actually transpired by the barley plants. Probably the remainder was lost by evaporation rather than by deep percolation, because the rainfall was distributed rather evenly throughout the season, with an inch or less per month from September to May, except that January had more than 3 inches.

Power, Grunes, and Reichman (1961) studied the growth of wheat in relation to moisture supply and phosphorus fertilizer at Sidney, Montana. Figures 16 and 17 show their data on dry-matter production, not included in the published results but obtained from the authors and plotted here against total water use. The field plots were sampled for yield of dry matter and for soilmoisture content at seeding, on April 30,1958 , and at four stages of growth: on June 2, June 25, July 22, and August 8. Dry-matter production and water use were related linearly throughout the period of growth from seeding to harvest, with correlation coefficients of 0.93 and 0.99 . Plots fertilized with 11 pounds per acre of phosphorus (fig. 17) showed more efficient water use than did the unfertilized plots (fig. 16), as indicated by a higher regression coefficient $\left(k_{f}\right)$. However, the difference is barely significant at the 5 per cent level. Yield from fertilized plots was 531 pounds of dry matter per acre-inch of water used; yield from unfertilized plots was 424 pounds. The standard error of regression is 20.15 for the fertilized plots and 45.65 for the unfertilized. The inter-

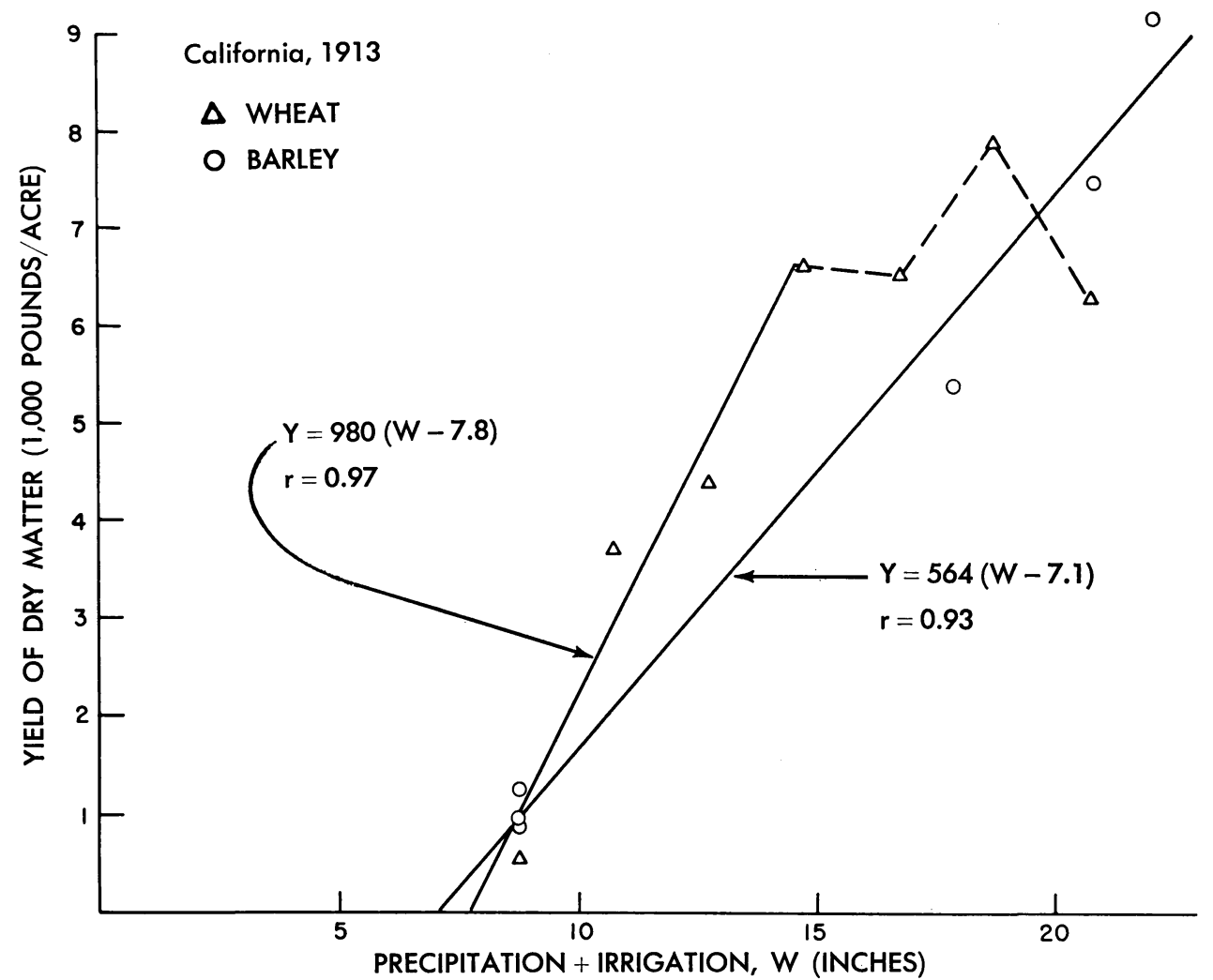

Fig. 15. Relationship between yield of dry matter $(Y)$ and total amount of water $(W)$ supplied by precipitation and irrigation. Field data of Beckett and Huberty (1928). 


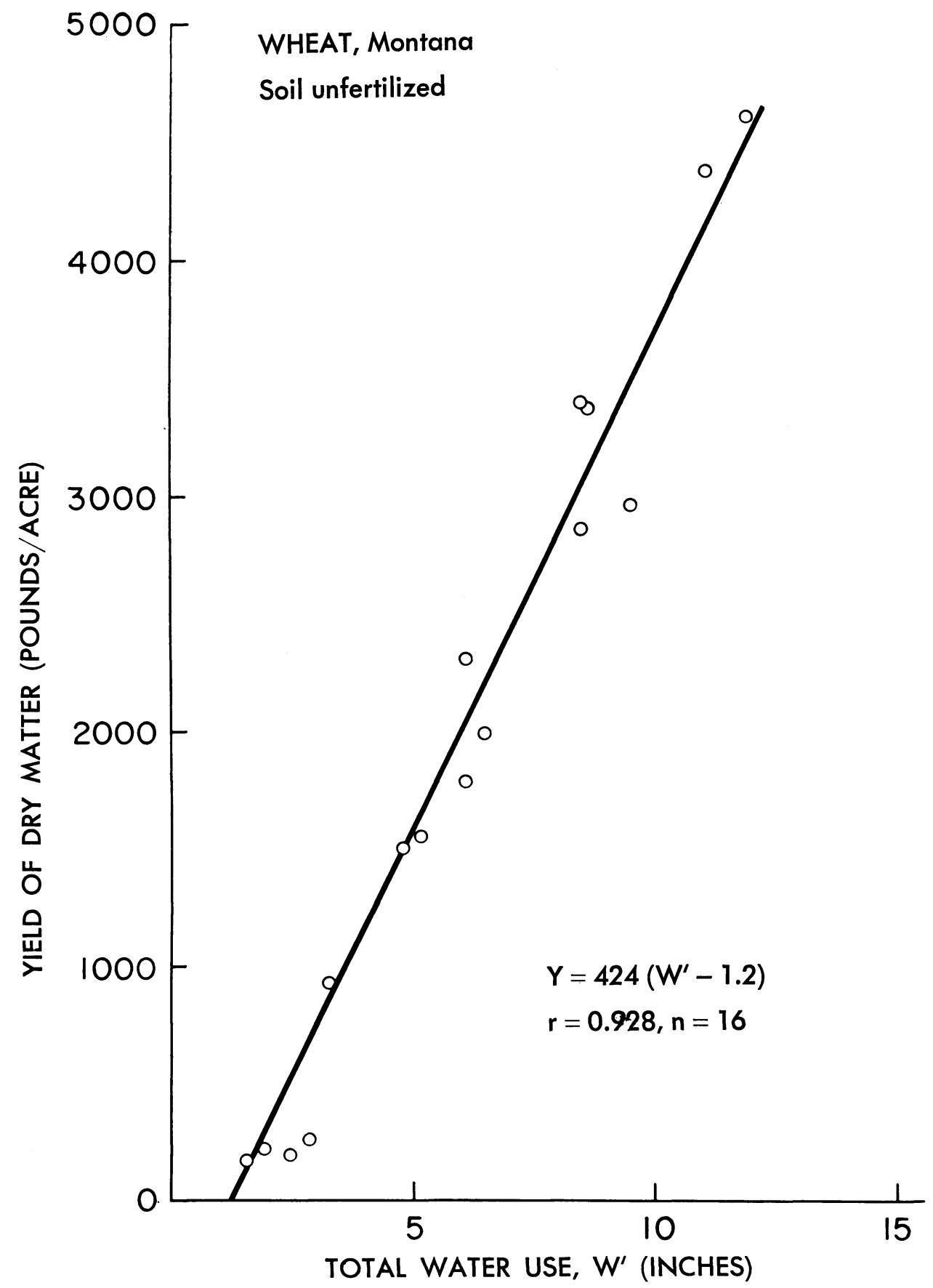

Fig. 16. Relationship between yield of dry matter $(\boldsymbol{Y})$ and total water use ( $W^{\prime}$ ) on unfertilized soil. Each point is the mean of four plots. Field data of Power, Grunes, and Reichman (1961). 


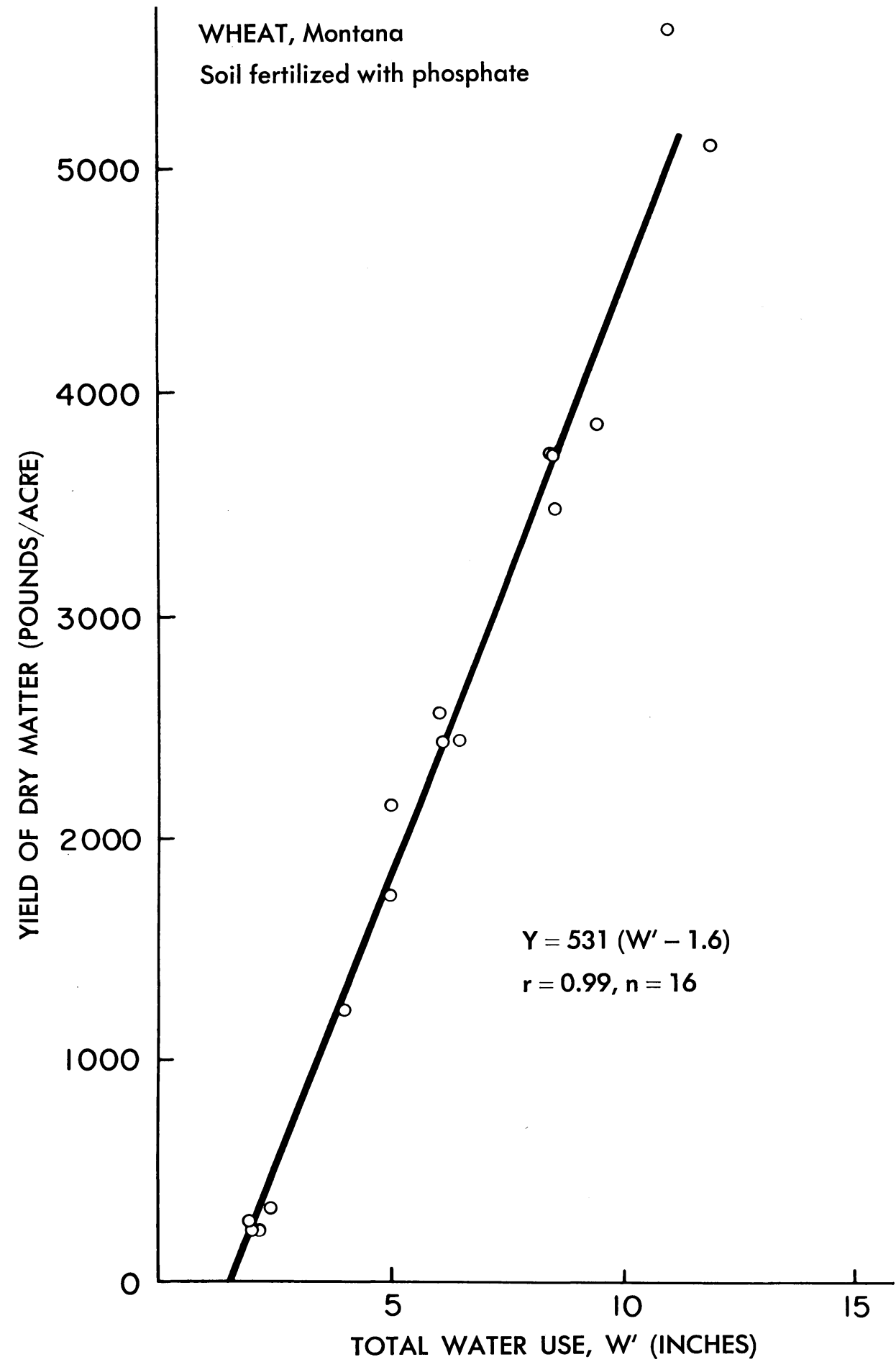

Fig. 17. Relationship between yield of dry matter $(Y)$ and total water use ( $W^{\prime}$ ) on soil fertilized with phosphate. Each point is the mean of four plots. Field data of Power, Grunes, and Reichman (1961). 
cepts of the $Y=0$ axis represent 1.2 and 1.6 inches of water-presumably the amounts of precipitation diverted from the soil or lost by evaporation from it. The difference between these amounts is not statistically significant. No percolation losses were detected.

The relative humidity at Sidney, Montana, during June and July, 1958, averaged about 55 per cent, nearly the same as the average at Akron, Colorado, during the period when Briggs and Shantz were making measurements. Therefore, it would be expected that the regression coefficients for wheat at Sid- ney would be about the same as those at Akron. The 531 pounds of wheat dry matter per acre-inch of water used on fertilized soil at Sidney was considerably higher than the yield at Akron, but the 424 pounds on unfertilized soil at Sidney was about the same as the yield at Akron. As with the alfalfa data, the regression coefficients for wheat plants grown in the field were slightly higher than for those grown in pots. In other words, container-grown plants at Akron showed the same relationship to field-grown plants at Sidney as to those at Davis.

\section{APPLICATIONS OF THE PRINCIPLES}

The relationships based on equations (1), (2a), and (4) yield new insight into the efficient use of water by plants, as shown in the above interpretations of field experiments. Disparate results obtained in experiments on water-use efficiency in different years and different localities and on soils of different fertility can be reconciled or properly compared if the effects of climate and soil fertility are taken into account, as by equations (2a) and (4). Only with these factors accounted for can any deviation from a strict proportionality between yield of dry matter and water use be explained, as in figures 13, 14, and 15 .

The data show that a given amount of added water will result in more plant growth in an area of high atmospheric humidity than in one of low humidity. Where irrigation water is very scarce, it is clear that humidity might well be an important consideration in determining the allocation of irrigation water to different parts of an area.

Students of plant ecology should be able to apply these principles to the analysis of factors that affect plant distribution where moisture is a limiting factor in plant survival. Even though temperature and precipitation are similar in two areas, the factor of atmospheric humidity may well play an important role in determining the kinds of plants that will predominate in each area.

Briggs and Shantz (1913a) found that Esperanza, a drought-resistant variety of corn from Mexico, has a significantly lower water requirement than the corn varieties commonly grown in the Midwest. Plant breeders interested in developing varieties of crops for desert regions might find equation (2a) helpful in isolating the plant factors involved in adaptation to low humidity.

In many kinds of plant-growth experiments, it is desirable to follow the rate of growth without disturbing the plants. Under controlled conditions, the simple equation (1) can often be used for this purpose; if the environment is not kept constant, equation (2a) may be more useful.

Arkley and Ulrich (1962) suggested the use of potential evapotranspiration $\left(E T_{p}\right)$ and actual evapotranspiration $\left(E T_{a}\right)$, calculated from climatic data, as indexes of potential plant growth in the classification of climate and land. It now appears that a correction for atmospheric humidity should be applied to these values if they are to be useful over more than a limited area. The more universally applicable indexes would be $E T_{p} /(100-H)$ and $E T_{a} /(100-H)$. 


\section{SUMMARY AND CONCLUSIONS}

This study has revealed that most of the differences in the transpiration ratios obtained for a given plant in different seasons or at different locations are due primarily to differences in either climatic conditions or soil fertility. A correction for climate based on mean monthly relative atmospheric humidity makes it possible to combine the data on yield and transpiration from different years and different localities, with correlation coefficients greater than 0.95 . This amount of correlation $\left(r^{2}=0.90\right)$ accounts for about 90 per cent of the variation among different experiments, provided that soil fertility is controlled at a constant level. The data available for determining a correction based on differences in soil fertility are less reliable than those used for the humidity correction, but the combined data from different workers suggest that a tentative relationship, equation (4), accounts for about 75 per cent of the variability other than that due to climatic differences. Equation (5) combines the two corrections, but this requires the assumption that there is no interaction between the effects of the two variables, relative humidity and soil fertility.

Examination of field experiments in the light of these principles sheds new light on the efficiency of water use by plants. When yield of dry matter is plotted against water use, the slope of the straight-line portion of the curve can be interpreted in terms of soil fertility or of atmospheric humidity, whichever is subject to variation. Deviation from a straight line with increasing moisture reveals the effect of overirrigation; reversal in slope suggests waterlogging or poor aeration in the soil. An intercept of the axis of zero yield or of zero water use can be interpreted in terms of water lost or of water used but unaccounted for by irrigation or precipitation.

In conclusion, it seems evident that quantitative expressions for the relationship between plant growth and transpiration and for the effect thereon of changing soil or environmental conditions should be significant in any study concerned with the use of water by plants and also in some other kinds of plant-growth research. 


\section{LITERATURE CITED}

ARKLEY, RODNEY J., and RUdOLPH ULRICH

1961. Climatic limitations on plant growth evaluated by balancing soil moisture against evaporation and transpiration. California Agr. 15(1):4-6.

1962. The use of calculated actual and potential evapotranspiration for estimating potential plant growth. Hilgardia 32(10):443-69.

BECKeTT, S. H., and MARTIN R. HUBERTY

1928. Irrigation investigations with field crops at Davis, and at Delhi, California, 1909-1925. California Agr. Exp. Sta. Bul. 450. 24 pp.

BeCKetT, S. H., and R. D. Robertson

1917. The economical irrigation of alfalfa in Sacramento Valley, California. California Agr. Exp. Sta. Bul. 280:271-94.

Blanex, H. F., and W. D. Criddle

1950. Determining water requirements in irrigated areas from climatological and irrigation data. U. S. Soil Conserv. Serv. Tech. Bul. 96. 44 pp.

Boonstra, A. E. H. R.

1934. Physiologisch onderzoek ten dienste van de plantenveredeling. (Thesis) Utrecht. (Not seen.)

1942. Rasverschillen bij bieten. VI. Meded. Inst. Suikerbietent. 12:13-96. (Not seen.)

BRIGGS, L. J., and H. L. Shantz

1913a. The water requirement of plants. I. Investigations in the Great Plains in 1910 and 1911. U. S. Bur. Plant Indus. Bul. 284. 49 pp.

1913b. The water requirement of plants. II. A review of the literature. U. S. Bur. Plant Indus. Bul. 285.96 pp.

1914. Relative water requirements of plants. Jour. Agr. Res. 3:1-63.

Dehtrain, P. P.

1892. La transpiration des végétaux et l'emploi des engrais. Ann. Agron. (Paris) 18:465-86. DE WIT, C. T.

1958. Transpiration and crop yields. Verslag. van Landbouwk. Onderzoek. No. 64. 6. 88 pp.

FORTIER, SAMUEL

1903. Soil moisture in relation to crop yield. Montana Agr. Exp. Sta. Ann. Rept. 9 (1902). (See p. 107.)

HAGAN, R. M., Y. VAadia, and M. B. RusselL

1959. Interpretation of plant responses to soil moisture regimes. Advances in Agron. 11:77-98.

Halkias, N. A., F. J. VeihmeYer, and A. H. Hendrickson

1955. Determining water needs for crops from climatic data. Hilgardia 24(9):207-33.

HELLRIEGEL, F. H.

1883. Verhältnis zwischen Produktion und Verdunstung. Beiträge zu den Naturwissenschaftlichen Grundlagen des Ackerbaus. Braunschweig. pp. 622-64. (Not seen.)

KIESSELBACH, T. A.

1916. Transpiration as a factor in crop production. Nebraska Agr. Exp. Sta. Res. Bul. 6. $214 \mathrm{pp}$.

KRAMER, P. J.

1959. The role of water in the physiology of plants. Advances in Agron. 11:51-70.

LETEY, J., O. R. LUNT, L. H. STOLZY, and T. E. SzuszKIEwicz

1961. Plant growth, water use and nutritional response to rhizosphere differentials of oxygen concentration. Soil Sci. Soc. Amer. Proc. 25:183-86.

LIEBSCHER, GEORG

1895. Untersuchungen über die Bestimmung des Düngerbedürfnisses der Ackerböden und Kulturpflanzen. Jour. f. Landw. 43:49-216.

MaschHAUPt, J. G.

1938. Lysimeteronderzoekingen aan het Rijkslandbouwproefstation te Groningen en Elders. İ. Regenval, drainage en verdamping. Verslag. van Landbouwk. Onderzoek. No. 44-

Penman, H. L. (1)A. 184 pp. (English summary.)

1948. Natural evaporation from open water, bare soil and grass. Proc. Roy. Soc. London. Ser. A, 193:120-45. 
Power, J. F., D. L. Grunes, and G. A. Reichman

1961. The influence of phosphorus fertilization and moisture on growth and nutrient absorption by spring wheat, I. Plant growth, $\mathrm{N}$ uptake, and moisture use. Soil Sci. Soc. Amer. Proc. 25:207-10.

Pruiti, W. O.

1958. Irrigation timetable. What's New in Crops and Soils 10(April-May): 11-13.

SCHROEDER, M. R.

1896. Razvitie i isparenie iachmeaê pri razlichnoı̆ vlazhnosti i pitatel nosti substrata. Izv. Moskov. Selsk. Khoz. Inst. 2 (kniga 1). (Ann. Inst. Agron. Moscou 2 (livr. 1) :188-226.) (Not seen.)

Shantz, H. L., and Lydia N. Piemeisel

1927. The water requirement of plants at Akron, Colo. Jour. Agr. Res. 34:1093-1190.

THORNTHWAITE, C. W.

1948. An approach toward a rational classification of climate. Geog. Rev. 38:55-94.

VAN DER PAAUW, F.

1949. Water relations of oats with attention to the influence of periods of drought. Plant and Soil 1:303-42.

VON SEELHORST, CONRAD

1899. Über den Wasserverbrauch der Haferpflanze bei verschiedenem Wassergehalt und bei verschiedener Düngung des Bodens. Jour. f. Landw. 47:369-78.

WILFARTH, HERMANN, and G. WIMMER

1902. Die Wirkung des Kaliums auf das Pflanzenleben nach Vegetationsversuchen mit Kartoffeln, Tabak, Buchweizen, Senf, Zichorien und Hafer. Arb. Deut. Landw. Gesell. (Berlin) Heft 68. 106 pp.

WIMMER, G., [ED.]

1908. Nach welchen Gesetzen erfolgt die Kaliaufnahme der Pflanzen aus dem Boden\& Arb. Deut. Landw. Gesell. (Berlin) Heft 143. 169 pp. 
The journal HILGARDIA is published at irregular intervals, in volumes of about 650 to 700 pages. The number of issues per volume varies.

Single copies of any issue may be obtained free, as long as the supply lasts; please request by volume and issue number from:

\author{
Agricultural Publications \\ University Hall \\ University of California \\ Berkeley 4, California
}

The limit to nonresidents of California is 10 separate titles. The limit to California residents is 20 separate titles.

The journal will be sent regularly to libraries, schools, or institutions in one of the following ways:

1. In exchange for similar published material on research.

2. As a gift to qualified repository libraries only.

3. On a subscription basis_ $\$ 7.50$ a year paid in advance. All subscriptions will be started with the first number issued during a calendar year. Subscribers starting during any given year will be sent back numbers to the first of that year and will be billed for the ensuing year the following January. Make checks or money orders payable to The Regents of The University of California; send payment with order to Agricultural Publications at above address. 